\title{
Beneficial effects of plant-associated microbes on indoor microbiomes and human health?
}

\author{
Gabriele Berg $^{1 *}$, Alexander Mahnert ${ }^{1}$ and Christine Moissl-Eichinger ${ }^{2}$ \\ 1 Institute of Environmental Biotechnology, Graz University of Technology, Graz, Austria \\ 2 Institute for Microbiology and Archaea Center, University of Regensburg, Regensburg, Germany \\ *Correspondence: gabriele.berg@tugraz.at
}

Edited by:

Martin Grube, Karl-Franzens-University Graz, Austria

Reviewed by:

Parag Vaishampayan, California Institute of Technology, USA

Keywords: interplay of plant -and indoor microbiomes, management of beneficial microbes, next-generation sequencing, houseplants, omicstechnologies

\section{PLANT MICROBIOMES-AN INTRODUCTION}

Just like humans, plants have recently been recognized as meta-organisms, possessing a distinct microbiome and revealing close symbiotic relationships with their associated microorganisms (Berg et al., 2013; Mendes et al., 2013). Each plant harbor specific species to a certain degree but also cosmopolitan and ubiquitous microbial strains; the majority of them fulfill important host as well as ecosystem functions (rev. in Berg and Smalla, 2009). In addition to the microbe-rich rhizosphere, which has been studied extensively, the phyllosphere is of special interest for the study of indoor microbiomes due to its large and exposed surface area and its remarkable microbial diversity (Lindow and Leveau, 2002; Lindow and Brandl, 2003; Redford et al., 2010; Meyer and Leveau, 2012; Vorholt, 2012; Rastogi et al., 2013). In addition to the majority of beneficial and neutral inhabitants, all plantassociated microbiomes contain plant as well as human pathogens (Berg et al., 2005; Mendes et al., 2013). A broad spectrum of plant pathogens is well-known from disease outbreaks. Human pathogens belong mainly to the so called opportunistic or facultative human pathogens such as Burkholderia cepacia, Pseudomonas aeruginosa or Stenotrophomonas maltophilia, which cause diseases only in patients with predisposition or in hospital (Berg et al., 2005; Ryan et al., 2009).

Microbiomes of humans and plants are currently intensively studied using the same methods and addressing similar scientific questions (Ramírez-Puebla et al., 2013). However, knowledge about the microbiomes' interaction, microbial dynamics and exchange in a certain biotope or even indoor environment is very much limited. Although the composition and function of plant microbiomes is well-studied, there is still little to no information regarding their overlap, interaction with -and impact on other microbiomes or the microbiomeharboring hosts. Information is available about the connection of soil and rhizosphere microbial diversity, which share a selective sub-set (Smalla et al., 2001). The root-soil interface is the selection site for plant-associated bacteria by root exudates, which acts as chemo-attractants as well as repellents to which bacteria respond (Badri and Vivanco, 2009). In addition, plant defense signaling play a role in this process (Doornbos et al., 2012). For the phyllosphere we know that there is only a part of residents, while a substantial part of bacteria is shared with the air microbiome (Lindow and Brandl, 2003). Based on these data, a strong interaction and exchange of rhizosphere and phyllosphere microbiomes with other microbiomes is obvious. However, this opinion paper focuses on the question, if there is also a connection from plant-to indoor microbiomes as well as an impact on human health.

\section{INDOOR MICROBIOMES- IMPORTANCE AND ORIGIN}

Despite the fact that the majority of our lifetime is spent in indoor environments such as home, work place, or public buildings, our knowledge of microbial diversity inside buildings is limited. We are not alone in these indoor environments: they provide new habitats and residence to numerous microbial communities comprising possibly hundreds of individual bacterial, archaeal and fungal species including diverse viruses. Recent studies analyzed potentially pathogenic and allergenic indoor microorganisms with mainly cultivation-based methods (Täubel et al., 2009; Yamamoto et al., 2011). Since the fraction of cultivable microbes on one specific medium is extremely low, information about specifically-adapted microorganisms, or those with special needs, remains inaccessible by standard cultivation assays. Recently, however, the application of molecular methods, including next generation sequencing (NGS) techniques has provided new insights into indoor microbial communities, revealing a generally high prokaryotic diversity including diverse bacterial, archaeal and fungal phyla (Flores et al., 2011, 2013; Moissl-Eichinger, 2011; Hewitt et al., 2012, 2013; Kembel et al., 2012; Dunn et al., 2013; Kelley and Gilbert, 2013; Meadow et al., 2013).

Indoor microbial communities are an important component of everyday human health (Arundel et al., 1986; Lee et al., 2007; Kembel et al., 2012). Due to human activity and high emission rate of up to $10^{6}$ bacteria per person-hour as measured via $16 \mathrm{~S}$ rRNA gene quantification from aerosols (Qian et al., 2012), indoor environments are strongly influenced by typically human-associated bacteria (Fierer et al., 2008). Hence, built environments like hospitals are more easily colonized to a large extent by patient-associated microbes (Oberauner 
et al., 2013). As a result, many patients in hospitals and especially in intensive care units (ICUs) develop hospitalacquired "nosocomial infections" that compound their underlying severe disease (Vincent et al., 1995; Plowman, 2000). Moreover, these nosocomial infections remain among the leading causes of death in developed country hospitals. The risk to get nosocomial infections for patients in European ICUs was reported as 45\% (Plowman, 2000). Hospital surfaces are often overlooked reservoirs for these bacteria (Hota, 2004; Gastmeier et al., 2005; Kramer et al., 2006). Apart from hospitals, indoor microorganisms affect human health as allergenic agents as well (Hanski et al., 2012). Indoor microorganisms are also involved in the development of the Sick Building Syndrome (SBS), which causes symptoms such as sensory irritation of the eyes, nose, and throat, neurotoxic or general health problems, skin irritation, non-specific hypersensitivity reactions, and odor and taste sensations (Godish, 2001).

Indoor microbiomes originate primarily from human skin, pets, or the outside air (Flores et al., 2011; Kembel et al., 2012; Meadow et al., 2013). Plants as a source of indoor microbes are so far less considered. However, air-borne microbes as substantial part-bacteria, fungi or microscopic algae-are scattered and can travel long distances such as in the wind or in clouds before returning to ground-level (Hamilton and Lenton, 1998). They have received more attention because they can serve as nuclei for condensation and as such influence our world climate as rainmaking bacteria. Interestingly, cloud and hailstone studies indicated plant-surface bacteria as the dominant source of these rain-making microbes (Morris et al., 2008; Šantl-Temkiv et al., 2013). In addition, little is known about the impact of houseplants and its microbes, although older studies indicate indoor plants as important source (Burge et al., 1982).

Comparing indoor with plant microbiomes, it is our opinion that both outside and inside plants are of importance for our indoor microbiome. Plants provide beneficial bacteria for indoor rooms and therefore can positively influence human health. The following facts support our opinion about the importance of plants as source for a beneficial microbial biodiversity:

1. Empirically the positive effects of houseplants and flowers are wellknown, but there is also evidence for psychological effects such as stress reduction and creative task performance (Fjeld et al., 1998; Shibata and Suzuki, 2004; Chang and Chen, 2005; Bringslimark et al., 2007; Dijkstra et al., 2008). In addition houseplants feature a remarkable capacity to improve indoor air quality (Orwell et al., 2004). This melioration of indoor air is not only due to the filtering capacity of plant leaves, but also by the degrading effects of their root associated microbes (Pegas et al., 2012 up to 90\% formaldehyde removal during night according to Kim et al., 2008).

2. Plant DNA as frequently detected as chloroplast 16S rRNA gene sequences in amplicon surveys is a substantial part of all indoor microbiomes, but mainly filtered out for the presentation of data (Oberauner et al., 2013). This emphasizes, that pollen and seeds of plants, which are densely colonized by bacteria (Fürnkranz et al., 2012) are dispersed into the indoor environment and thus provide excellent shuttles for microbiome exchange.

3. Typical and often dominant plantassociated bacteria are members of the indoor microbiome. A relationship of bacteria genera occurring on plants and indoors is given in Figure 1. There are many ways for plant microbes to enter the built environment; as already mentioned on pollen, seeds, fog, soil on shoes, flowers, fruits and vegetables as well as transmitted by animals and other visitors.

4. At species level, no differentiation was possible for clinical and plantassociated isolates. This was studied for Burkholderia cepacia, Pseudomonas aeruginosa and Stenotrophomonas maltophilia (Ryan et al., 2009; Martins et al., 2013). Unfortunately, these plant-associated bacteria can infect immuno-compromised patients with high predisposition in hospitals. On the one hand this is an evidence for the interplay of the plant and indoor microbiome, but on the other hand it highlights the beneficial balance, which is necessary between microorganisms and hosts.

5. Interestingly, Thaumarchaeota, originally described to be associated with ammonia-oxidation in soil and the rhizosphere of plants, have been found on human skin (Probst et al., 2013). Currently it is unknown, whether the human skin archaea have positive or negative effect on human health and whether they have different genomic capabilities compared to their soilrelatives. However, it becomes clear, that closely related microorganisms can exist in different microbiomes, based on a dynamic exchange or distribution and subsequent development of adaptation strategies.

Based on these facts, we speculate the following:

Enclosed environments and their microbiomes-like private/public buildings, hospitals, and clean rooms, which are more or less separated from outside, are especially shaped by human influence and human associated microbes (Hospodsky et al., 2012; Dunn et al., 2013). Hence, microbial diversity is altered and partially reduced compared to the outdoor environment. A reduction in microbial diversity is well known to facilitate dominant proliferations of certain strains, which might bear the risk to have a negative effect toward our health. To increase microbial diversity in an indoor environment we could simply open our windows instead of using air-condition (Hanski et al., 2012; Kembel et al., 2012; Meadow et al., 2013). Alternatively, we could use potted houseplants in built environments as a source of microbial biodiversity and possibly beneficial microorganisms.

Microbes, which live in close vicinity to human beings, are adapted to us as symbionts, commensals, or pathogens, whereas these life-styles are changeable dependent on the host-microbe balance. Indoors we share these microbes, which might get deposited on various surfaces by one person and afterwards get collected by another. Human-associated microbes e.g., skin associated, are confronted with totally new biotic and abiotic factors in the built environment. Here they have to adapt to new surface materials, compete with 


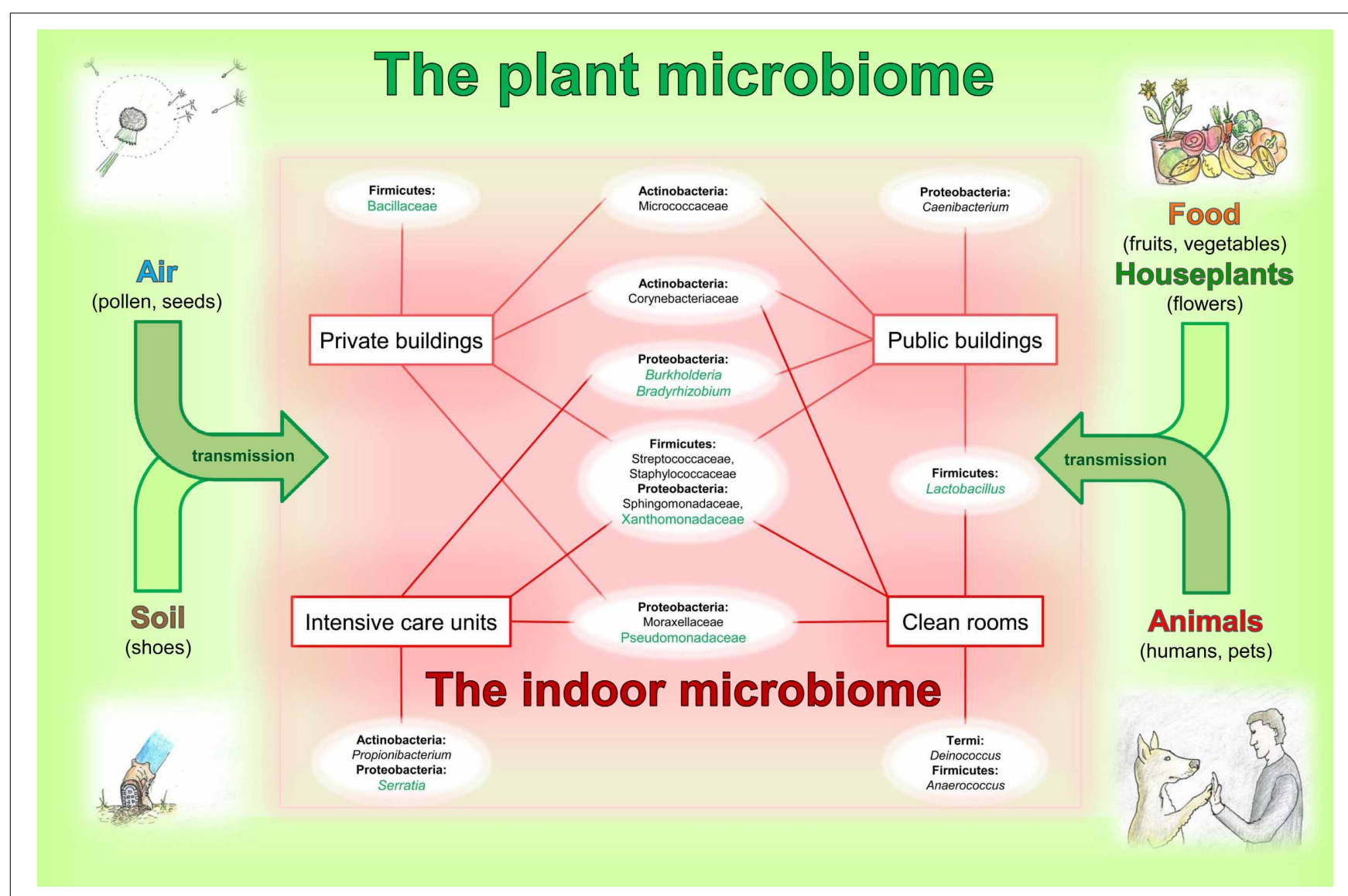

FIGURE 1 | Relationships between the plant and indoor microbiome. The indoor microbiomes, influenced by transmissions via air, soil, food, houseplants and animals from plant microbiomes, presents an overview on typical and dominant bacterial groups occurring in the built environment. Schematic chart represents occurrence of the bacterial inhabitants indoors.
Bacterial families and genera (white ellipses) are arranged according to their phylum affiliation (bold) and are connected to certain types of the built environments (red squares). Taxa highlighted in green are typical phyla detectable in plant microbiomes. This image has no demand of being complete. others for scarce nutrients and withstand stresses associated to cleaning reagents etc. However, in the case of houseplants we allow them to proliferate in a protected environment. Plant associated microbes stay on the leave or stem surface, where they have adapted to and are sheltered from cleaning procedures. Although these phyllosphere communities are confronted with an absence of direct sun light and rain as well as other changed meteorological parameters like air/dust turbulences, their rhizosphere and surrounding soil communities stay in their natural habitat. Hence, these well balanced plant communities, which we bring inside, have the potential to balance an indoor microbiome, by increasing its diversity and filter airborne microbes.

\section{CONCLUSION}

Members of the plant microbiome are an important source for indoor microbiomes. Both, plants from inside and outside can contribute to the microflora. Plant-associated bacteria could act as counterparts against pathogens within the microbial ecosystems. They stabilize the ecosystem, enhance biodiversity and avoid outbreaks of pathogens. However, more research is necessary to understand the microbiology of indoor environments. Currently used cleaning and hygiene strategies in built environments especially in hospitals and ICUs often promote multi-resistant pathogens instead of supporting beneficials. In future, it is important to re-think our understanding of necessary sterility and our relationship to our surrounding microbiomes. This "paradigm shift in ecology" is not only required for plants, humans (Jones, 2013) but also for our environment. Fortunately, "omics"-technologies guided by next-generation sequencing and microscopic techniques allow us now a much better assessment of them. Moreover, we can develop management strategies for beneficial interactions.

\section{REFERENCES}

Arundel, A. V., Sterling, E. M., Biggin, J. H., and Sterling, T. D. (1986). Indirect health effects of relative humidity in indoor environments. Environ. Health Perspect. 65, 351-361.

Badri, D. V., and Vivanco, J. M. (2009). Regulation and function of root exudates. Plant Cell Environ. 32, 666-681. doi: 10.1111/j.1365-3040.2009. 01926.x 
Berg, G., Eberl, L., and Hartmann, A. (2005). The rhizosphere as a reservoir for opportunistic human pathogenic bacteria. Environ. Microbiol. 7, 1673-1685. doi: 10.1111/j.1462-2920.2005.00891.x

Berg, G., and Smalla, K. (2009). Plant species and soil type cooperatively shape the structure and function of microbial communities in the rhizosphere. FEMS Microbiol. Ecol. 68, 1-13. doi: 10.1111/j.1574-6941.2009.00654.x

Berg, G., Zachow, Z., Müller, H., Philipps, J., and Tilcher, R. (2013). Next-generation bio-products sowing the seeds of success for sustainable agriculture. Agronomy 3, 648-656. doi: 10.3390/agronomy3040648

Bringslimark, T., Hartig, T., and Patil, G. G. (2007). Psychological benefits of indoor plants in workplaces: putting experimental results into context. HortScience 42, 581-587.

Burge, H. A., Solomon, W. R., and Muilenberg, M. L. (1982). Evaluation of indoor plantings as allergen exposure sources. J. Allergy Clin. Immunol. 70, 101-108. doi: 10.1016/0091-6749(82)90236-6

Chang, C.-Y., and Chen, P.-K. (2005). Human response to windows views and indoor plants in the workplace. HortScience 40, 1354-1359.

Dijkstra, K., Pieterse, M. E., and Pruyn, A. (2008). Stress-reducing effects of indoor plants in the built healthcare environment: the mediating role of perceived attractiveness. Prev. Med. 47, 279-283. doi: 10.1016/j.ypmed.2008.01.013

Doornbos, R. F., van Loon, L. C., and Bakker, P. A. H. M. (2012). Impact of root exudates and plant defense signalling on bacterial communities in the rhizosphere. Agron. Sustain. Dev. 32, 227-243. doi: 10.1007/s13593-011-0028-y

Dunn, R. R., Fierer, N., Henley, J. B., Leff, J. W., and Menninger, H. L. (2013). Home life: factors structuring the bacterial diversity found within and between homes. PLOS ONE 8:e64133. doi: 10.1371/journal.pone.0064133

Fierer, N., Hamady, M., Lauber, C. L., and Knight, R. (2008). The influence of sex, handedness, and washing on the diversity of hand surface bacteria. Proc. Natl. Acad. Sci. U.S.A. 105, 17994-17999. doi: 10.1073/pnas.0807920105

Fjeld, T., Veiersted, B., Sandvik, L., Riise, G., and Levy, F. (1998). The effect of indoor foliage plants on health and discomfort symptoms among office workers. Indoor Built Environ. 7, 204-209. doi: $10.1159 / 000024583$

Flores, G. E., Bates, S. T., Caporaso, J. G., Lauber, C. L., Leff, J. W., Knight, R., et al. (2013). Diversity, distribution and sources of bacteria in residential kitchens. Environ. Microbiol. 15, 588-596. doi: 10.1111/1462-2920.12036

Flores, G. E., Bates, S. T., Knights, D., Lauber, C. L., Stombaugh, J., Knight, R., et al. (2011). Microbial biogeography of public restroom surfaces. PLoS ONE 6:e28132. doi: 10.1371/journal.pone.0028132

Fürnkranz, M., Lukesch, B., Müller, H., Huss, H., Grube, M., and Berg, G. (2012). Microbial diversity inside pumpkins: microhabitat-specific communities display a high antagonistic potential against phytopathogens. Microb. Ecol. 63, 418-428. doi: 10.1007/s00248-011-9942-4

Gastmeier, P., Schwab, F., Bärwolff, S., Rüden, H., and Grundmann, H. (2005). Correlation between the genetic diversity of nosocomial pathogens and their survival time in intensive care units. J. Hosp. Infect. 62, 181186. doi: 10.1016/j.jhin.2005.08.010

Godish, T. (2001). Indoor Environmental Quality. Boca Raton, FL: CRC Press, Lewis Publishers.

Hamilton, W. D., and Lenton, T. M. (1998). Spora and gaia: how microbes fly with their clouds. Ethol. Ecol. Evol. 10, 1-16. doi: 10.1080/08927014.1998.9522867

Hanski, I., Von Hertzen, L., Fyhrquist, N., Koskinen, K., Torppa, K., Laatikainen, T., et al. (2012). Environmental biodiversity, human microbiota, and allergy are interrelated. Proc. Natl. Acad. Sci. U.S.A. 109, 8334-8339. doi: 10.1073/pnas.1205624109

Hewitt, K. M., Gerba, C. P., Maxwell, S. L., and Kelley, S. T. (2012). Office space bacterial abundance and diversity in three metropolitan areas. PLoS ONE 7:e37849. doi: 10.1371/journal.pone.0037849

Hewitt, K. M., Mannino, F. L., Gonzalez, A., Chase, J. H., Caporaso, J. G., Knight R., et al. (2013). Bacterial diversity in two neonatal intensive care units (NICUs). PLoS ONE 8:e54703. doi: 10.1371/ journal.pone.0054703

Hospodsky, D., Qian, J., Nazaroff, W. W., Yamamoto, N., Bibby, K., Rismani-Yazdi, H., et al. (2012). Human occupancy as a source of indoor airborne bacteria. PLoS ONE 7:e34867. doi: 10.1371/ journal.pone.0034867

Hota, B. (2004). Contamination, disinfection, and cross-colonization: are hospital surfaces reservoirs for nosocomial infection? Clin. Infect. Dis. 39, 1182-1189. doi: 10.1086/424667

Jones, N. (2013). Food fuelled with fungi. Nature 504, 199. doi: $10.1038 / 504199$ a

Kelley, S. T., and Gilbert, J. A. (2013). Studying the microbiology of the indoor environment. Genome Biol. 14, 202. doi: 10.1186/gb-2013-14-2-202

Kembel, S. W., Jones, E., Kline, J., Northcutt, D., Stenson, J., Womack, A., et al. (2012). Architectural design influences the diversity and structure of the built environment microbiome. ISME J. 6, 1469-1479. doi: 10.1038/ismej. 2011.211

Kim, K. J., Kil, M. J., Song, J. S., and Yoo, E. H. (2008). Efficiency of volatile formaldehyde removal by indoor plants: contribution of aerial plant parts versus the root zone. J. Am. Soc. Hort. Sci. 133, 521-526.

Kramer, A., Schwebke, I., and Kampf, G. (2006). How long do nosocomial pathogens persist on inanimate surfaces? A systematic review. BMC Infect. Dis. 6:130. doi: 10.1186/1471-2334-6-130

Lee, L., Tin, S., and Kelley, S. T. (2007). Cultureindependent analysis of bacterial diversity in a child-care facility. BMC Microbiol. 7:27. doi: 10.1186/1471-2180-7-27

Lindow, S. E., and Brandl, M. T. (2003). Microbiology of the phyllosphere. Appl. Environ. Microbiol. 69, 1875-1883. doi: 10.1128/AEM.69.4.1875-1883.2003

Lindow, S. E., and Leveau, J. H. J. (2002). Phyllosphere microbiology. Curr. Opin. Biotechnol. 13, 238-243. doi: 10.1016/S0958-1669(02)00313-0

Martins, V. V., Pitondo-Silva, A., de Melo Manço, L., Falcão, J. P., Freitas, S. D., da Silveira, W. D., et al. (2013). Pathogenic potential and genetic diversity of environmental and clinical isolates of Pseudomonas aeruginosa. APMIS. doi: 10.1111/apm.12112
Meadow, J. F., Altrichter, A. E., Kembel, S. W., Kline, J., Mhuireach, G., Moriyama, M., et al. (2013). Indoor airborne bacterial communities are influenced by ventilation, occupancy, and outdoor air source. Indoor Air 24, 41-48. doi: 10.1111/ina. 12047

Mendes, R., Garbeva, P., and Raaijmakers, J. M. (2013). The rhizosphere microbiome: significance of plant beneficial, plant pathogenic, and human pathogenic microorganisms. FEMS Microbiol. Rev. 37, 634-663. doi: 10.1111/1574-6976.12028

Meyer, K. M., and Leveau, J. H. J. (2012). Microbiology of the phyllosphere: a playground for testing ecological concepts. Oecologia 168, 621-629. doi: 10.1007/s00442-011-2138-2

Moissl-Eichinger, C. (2011). Archaea in artificial environments: their presence in global spacecraft clean rooms and impact on planetary protection. ISME J. 5, 209-219. doi: 10.1038/ismej.2010.124

Morris, C. E., Sands, D. C., Vinatzer, B. A., Glaux, C., Guilbaud, C., Buffière, A., et al. (2008). The life history of the plant pathogen Pseudomonas syringae is linked to the water cycle. ISME J. 2, 321-334. doi: 10.1038/ismej.2007.113

Oberauner, L., Zachow, C., Lackner, S., Högenauer, C., Smolle, K. H., and Berg, G. (2013). The ignored diversity: complex bacterial communities in intensive care units revealed by $16 \mathrm{~S}$ pyrosequencing. Sci. Rep. 113, 1413. doi: 10.1038/ srep01413

Orwell, R. L., Wood, R. L., Tarran, J., Torpy, F., and Burchett, M. D. (2004). Removal of benzene by the indoor plant/substrate microcosm and implications for air quality. Water Air Soil Pollut. 157, 193-207. doi: 10.1023/B:WATE.0000038896.55713.5b

Pegas, P. N., Alves, C. A., Nunes, T., Bate-Epey, E. F., Evtyugina, M., and Pio, C. A. (2012). Could houseplants improve indoor air quality in schools? J. Toxicol. Environ. Health 75, 1371-1380. doi: 10.1080/15287394.2012.721169

Plowman, R. (2000). The socioeconomic burden of hospital acquired infection. Euro Surveill. 5, 49-50.

Probst, A. J., Auerbach, A. K., and Moissl-Eichinger, C. (2013). Archaea on human skin. PLoS ONE 8:e65388. doi: 10.1371/journal.pone.0065388

Qian, J., Hospodsky, D., Yamamoto, N., Nazaroff, W. W., and Peccia, J. (2012). Size-resolved emission rates of airborne bacteria and fungi in an occupied class room. Indoor Air 22, 339-351. doi: 10.1111/j. 1600-0668.2012.00769

Ramírez-Puebla, S. T., Servín-Garcidueñas, L. E., Jiménez-Marín, B., Bolaños, L. M., Rosenblueth, M., Martínez, J., et al. (2013). Gut and root microbiota commonalities. Appl. Environ. Microbiol. 79, 2-9. doi: 10.1128/AEM.02553-12

Rastogi, G., Coaker, G. L., and Leveau, J. H. (2013). New insights into the structure and function of phyllosphere microbiota through high-throughput molecular approaches. FEMS Microbiol. Lett. 348, 1-10. doi: 10.1111/1574-6968. 12225

Redford, A. J., Bowers, R. M., Knight, R., Linhart, Y., and Fierer, N. (2010). The ecology of the phyllosphere: geographic and phylogenetic variability in the distribution of bacteria on tree leaves. Environ. Microbiol. 12, 2885-2893. doi: 10.1111/j.14622920.2010.02258.x 
Ryan, R. P., Monchy, S., Cardinale, M., Taghavi, S., Crossman, L., Avison, M. B., et al. (2009). The versatility and adaptation of bacteria from the genus Stenotrophomonas. Nat. Rev. Microbiol. 7, 514-525. doi: $10.1038 /$ nrmicro2163

Shibata, S., and Suzuki, N. (2004). Effects of an indoor plant on creative task performance and mood. Scandinavian J. Psychol. 45, 373-381. doi: 10.1111/j.1467-9450.2004.00419.x

Smalla, K., Wieland, G., Buchner, A., Zock, A., Parzy, J., Kaiser, S., et al. (2001). Bulk and rhizosphere soil bacterial communities studied by denaturing gradient gel electrophoresis: plant-dependent enrichment and seasonal shifts revealed. Appl. Environ. Microbiol. 67, 4742-4751. doi: 10.1128/AEM.67.10.4742-4751.2001

Täubel, M., Rintala, H., Pitkäranta, M., Paulin, L., Laitinen, S., Pekkanen, J., et al. (2009). The occupant as a source of house dust bacteria. J. Allergy Clin. Immunol. 124, 834-840. doi: 10.1016/j.jaci.2009.07.045
Šantl-Temkiv, T., Finster, K., Dittmar, T., Munk Hansen, B., Thyrhaug, R., Woetmann Nielsen, N., et al. (2013). Hailstones: a window into the microbial and chemical inventory of a storm cloud. PLoS ONE 8:e53550. doi: 10.1371/journal.pone. 0053550

Vincent, J. L., Bihari, D. J., Suter, P. M., Bruining, H. A., White, J., Nicolas-Chanoin, M. H., et al. (1995). The prevalence of nosocomial infection in intensive care units in Europe. Results of the European Prevalence of Infection in Intensive Care (EPIC) study. EPIC international advisory committee. JAMA 274, 639-644. doi: 10.1001/jama.1995.0353008 0055041

Vorholt, J. A. (2012). Microbial life in the phyllosphere. Nat. Rev. Microbiol. 10, 828-840. doi: 10.1038/nrmicro2910

Yamamoto, N., Shendell, D. G., and Peccia, J. (2011). Assessing allergenic fungi in house dust by floor wipe sampling and quantitative PCR.
Indoor Air 21, 521-530. doi: 10.1111/j.16000668.2011.00732.x

Received: 27 September 2013; accepted: 10 January 2014; published online: 29 January 2014.

Citation: Berg G, Mahnert A and Moissl-Eichinger C (2014) Beneficial effects of plant-associated microbes on indoor microbiomes and human health? Front. Microbiol. 5:15. doi: 10.3389/fmicb.2014.00015

This article was submitted to Plant-Microbe Interaction, a section of the journal Frontiers in Microbiology.

Copyright (C) 2014 Berg, Mahnert and MoisslEichinger. This is an open-access article distributed under the terms of the Creative Commons Attribution License (CC BY). The use, distribution or reproduction in other forums is permitted, provided the original author(s) or licensor are credited and that the original publication in this journal is cited, in accordance with accepted academic practice. No use, distribution or reproduction is permitted which does not comply with these terms. 